\title{
Recognition of the parliamentarism transformation in Ukraine (1990-2014)
}

\author{
Maria Ivanovna Rosenko ${ }^{1 *}$, Elena Vladimirovna Skrebets $^{2}$, Svetlana Vitalievna Golikova ${ }^{2}$, \\ Sergey Andreevich Zaporozhets ${ }^{1}$, and Iracema Marisol Ruiz Medrano ${ }^{3}$ \\ ${ }^{1}$ Sevastopol State University, Law Institute, Department of Constitutional and Administrative Law, \\ Sevastopol, Russia \\ ${ }^{2}$ Sevastopol State University, Law Institute, Department of Theory and History of State and Law, \\ Sevastopol, Russia \\ ${ }^{3}$ Drug Enforcement Administration of the National Police of Nicaragua, Managua, Nicaragua
}

\begin{abstract}
The article examines the transformation of state reform in Ukraine, considers the reasons for the evolution of the political structuring of the Ukrainian parliament in the context of the procedures of the political crisis, systematizes the main reasons why the democratic transformations that have begun cannot achieve their main goal - the consolidation of democracy. It is noted that a lack of national consciousness, a low level of political culture, excessive ambitions of leaders, and their desire for power as a means of personal enrichment simulate conflicts of a destructive nature, threaten to deconstruct the political system and destroy the nation-state. It is indicated that the consequence of the political crisis may be a new revolution, which will not only lead to a change of the government form and the system of values but also the loss of statehood, with Ukraine entering the list of "falling states" and as result.

Keywords: democratic transition, political crisis, consolidation of democracy, elections, governmental system, public authorities, political conflict
\end{abstract}

\section{Introduction}

In the modern world, the introduction of democratic values into public relations is a prerequisite for any state. The most important task in achieving sustainable democratic governance is the problem of creating mechanisms for democratic transition.

In states where democracy descends from above on the initiative of the ruling circles, it can take the form of "alienness" to the national political culture and the whole mentality. For this reason, it is either rejected or takes forms that are far from the normative sample.

\footnotetext{
*Corresponding author: mariyair@mail.ru
} 


\section{Methods}

The study was based on a dialectical approach to the disclosure of legal phenomena and processes using general scientific (systemic, logical, analysis and synthesis) and specific scientific methods.

\section{$3 \quad$ Results}

Studies of socio-political processes and essential aspects of state reform in Ukraine have shown that the processes of political structuring in Ukrainian society are rather complicated and contradictory. The elections to the Verkhovna Rada, which have an impact on the rotational processes in the elite and are directly related to both the level of dynamism of the elites and the legitimacy of power in the state, can be considered the illustrative example.

The Verkhovna Rada, like the Ukrainian society, has not yet overcome the institutional and value factors inherent in the transition from authoritarianism to democracy.

Since Ukraine gaining independence, the history of modern Ukrainian parliamentarism has seven convocations of the Verkhovna Rada of Ukraine. The processes that have taken place over the past 25 years make it possible to identify the main trends and patterns of partyparliamentary structuring.

From the analysis of the processes of formation and development of party-political structuring in the Verkhovna Rada, five stages are conditionally identified, namely:

- Majority (post-Soviet) stage, associated with the activities of the Supreme Soviet of the Ukrainian SSR and the Verkhovna Rada of the first and second convocations (1990-1998);

- Majority-proportional (traditional) stage, associated with the activities of the Verkhovna Rada of Ukraine of the third and fourth convocations (1998-2005/2006);

- Proportional (reformist) stage, associated with changes to the Constitution, the transition to a parliamentary-presidential form of government, and qualitatively new political and legal conditions for the functioning of the institutions of the parliamentary majority and opposition.

- Post-reformist (2012-2014) stage, associated with a return to a mixed electoral system

- The newest (since 2014) stage, associated with holding the elections in the context of a political crisis, non-participation in the formation of the Verkhovna Rada of Crimea, Sevastopol, LPR, and DPR electorate.

The structuring of the party-political system through electoral systems is shown in TableШ.

Table $\square$. Party-political system vs electoral systems.

\begin{tabular}{|c|l|c|c|c|c|c|c|c|c|}
\hline Year & \multicolumn{1}{|c|}{$\mathbf{2}$} & $\mathbf{3}$ & $\mathbf{4}$ & $\mathbf{5}$ & $\mathbf{6}$ & $\mathbf{7}$ & $\mathbf{8}$ & $\mathbf{9}$ \\
\hline 1994 & Majority & 32 & & & & & $\begin{array}{l}\text { CPU - 90*, } \\
\text { Rukh - 20* }\end{array}$ & \\
\hline 1998 & $\begin{array}{l}\text { Majority- } \\
\text { proportional }\end{array}$ & 4 & 62 & $\begin{array}{c}21 \\
(9)\end{array}$ & $\begin{array}{c}7 \\
(1)\end{array}$ & 10.7 & 5.1 & $\begin{array}{l}\text { CPU - 84, } \\
\text { Rukh - 32 }\end{array}$ & $\begin{array}{l}51.5 \\
5\end{array}$ \\
\hline 2002 & $\begin{array}{l}\text { Majority- } \\
\text { proportional }\end{array}$ & 6 & 123 & $\begin{array}{c}21 \\
(12)\end{array}$ & $\begin{array}{c}3 \\
(3)\end{array}$ & 7.9 & 4.7 & $\begin{array}{l}\text { Our Ukraine }- \\
70, \\
\text { CPU - 59 }\end{array}$ & $\begin{array}{l}57.3 \\
3\end{array}$ \\
\hline 2006 & Proportional & 3 & 128 & $\begin{array}{c}29 \\
(16)\end{array}$ & $\begin{array}{c}3 \\
(2)\end{array}$ & 6.7 & 3.4 & $\begin{array}{l}\text { Party of of } \\
\text { Regions - 186, }\end{array}$ & $\begin{array}{l}70.0 \\
0\end{array}$ \\
\hline
\end{tabular}




\begin{tabular}{|c|c|c|c|c|c|c|c|c|c|}
\hline & & & & & & & & $\begin{array}{l}\text { Bloc of Yuliya } \\
\text { Tymoshenko - } \\
129\end{array}$ & \\
\hline 2007 & Proportional & 3 & 141 & $\begin{array}{c}10 \\
(10)\end{array}$ & $\begin{array}{c}2 \\
(3)\end{array}$ & 9.9 & 3.7 & $\begin{array}{l}\text { Party of } \\
\text { Regions }-175, \\
\text { Bloc of Yuliya } \\
\text { Tymoshenko - } \\
156\end{array}$ & $\begin{array}{l}73.5 \\
5\end{array}$ \\
\hline 2012 & $\begin{array}{l}\text { Majority- } \\
\text { proportional }\end{array}$ & 5 & 202 & $\begin{array}{l}21 \\
(5)\end{array}$ & $\begin{array}{c}5 \\
(0)\end{array}$ & 7.8 & 3.4 & $\begin{array}{l}\text { Party of } \\
\text { Regions }-72 \\
\text { Fatherland - } \\
62\end{array}$ & 59.5 \\
\hline 2014 & $\begin{array}{l}\text { Majority- } \\
\text { proportional }\end{array}$ & 5 & 254 & $\begin{array}{l}24 \\
(5)\end{array}$ & $\begin{array}{c}1 \\
(4)\end{array}$ & 8.3 & 3.4 & $\begin{array}{l}\text { People's Self- } \\
\text { Defense }-64 \\
\text { Bloc of Petr } \\
\text { Poroshenko - } \\
63 \\
\quad \text { Petro } \\
\text { Poroshenko } \\
\text { Bloc - } 63\end{array}$ & 56.4 \\
\hline
\end{tabular}

1 - System type, 2 - Voters, 3 - Number of registered parties, 4 - Number of parties that took part in elections, 5 -Qty. parties (blocs) that took part in the distribution of mandates, 6 - Effective qty. of electoral parties, 7 - Effective qty. of parliament parties, 8 - Two parties (blocks) received the largest number of Mandates in the proportional part, 9 - According to Mayer's classification, \% in the proportional part.

As can be seen from the diagrams, the electoral preferences in the state were divided almost equally, which required certain steps of the ruling elites, the use of various kinds of technologies to work with the regions, which did not support the candidate or party.

According to the "Against all" voting indicator, one can judge the level of absenteeism and determine measures to correct the political course, which makes it possible to timely respond to the existing challenges. The dynamics of voter turnout in the parliamentary elections and the presidential elections in Ukraine are shown in Figures 1, 2.

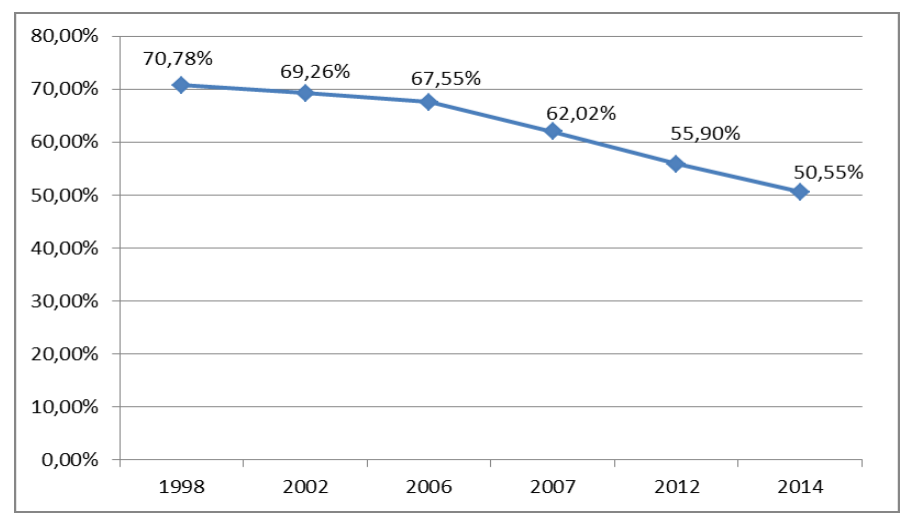




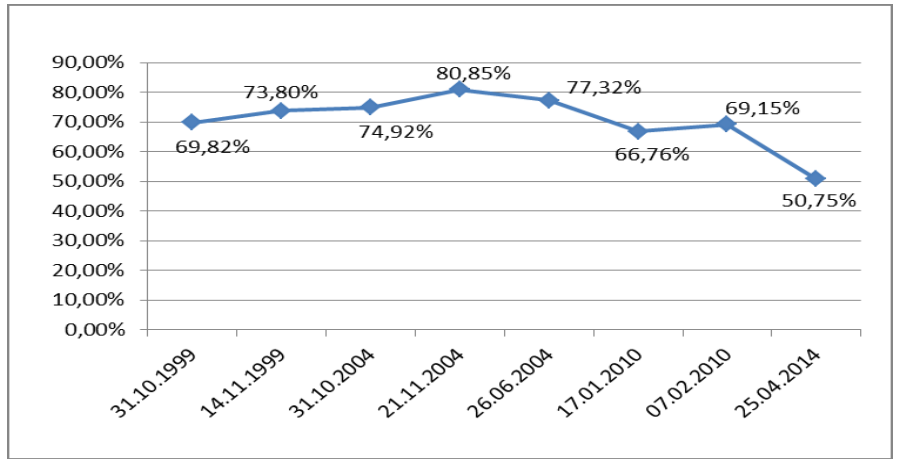

b

Fig. 1. Voter participation: at VRU elections (a), at the Ukraine presidential elections (b).

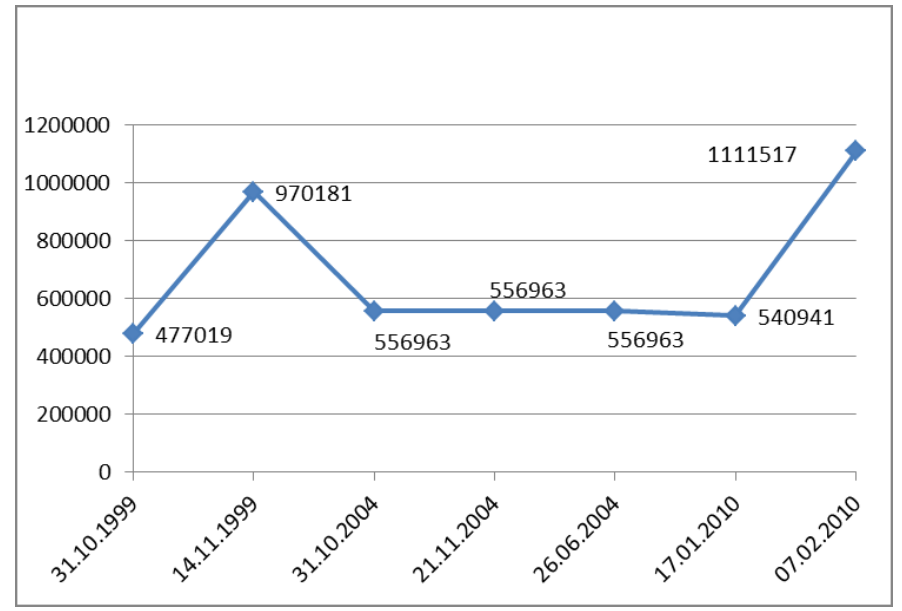

a

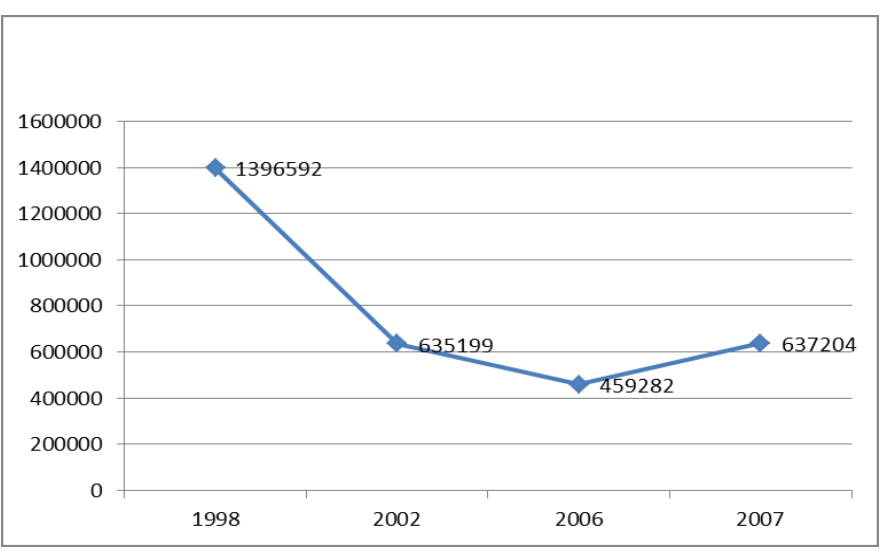

b

Fig. 2. Against all: the number of voters who spoke out "against all" in the presidential elections in Ukraine (a); the number of voters who spoke out "against all" in the parliamentary elections in Ukraine (b). 
As the events of late 2013 - early 2014 in Ukraine showed that the current government was unable to maintain political stability, which led to an increase in protest sentiments and subsequently to a complete unconstitutional change of government and the ruling party.

Figure 3 illustrates the lack of representation of political parties in parliament.

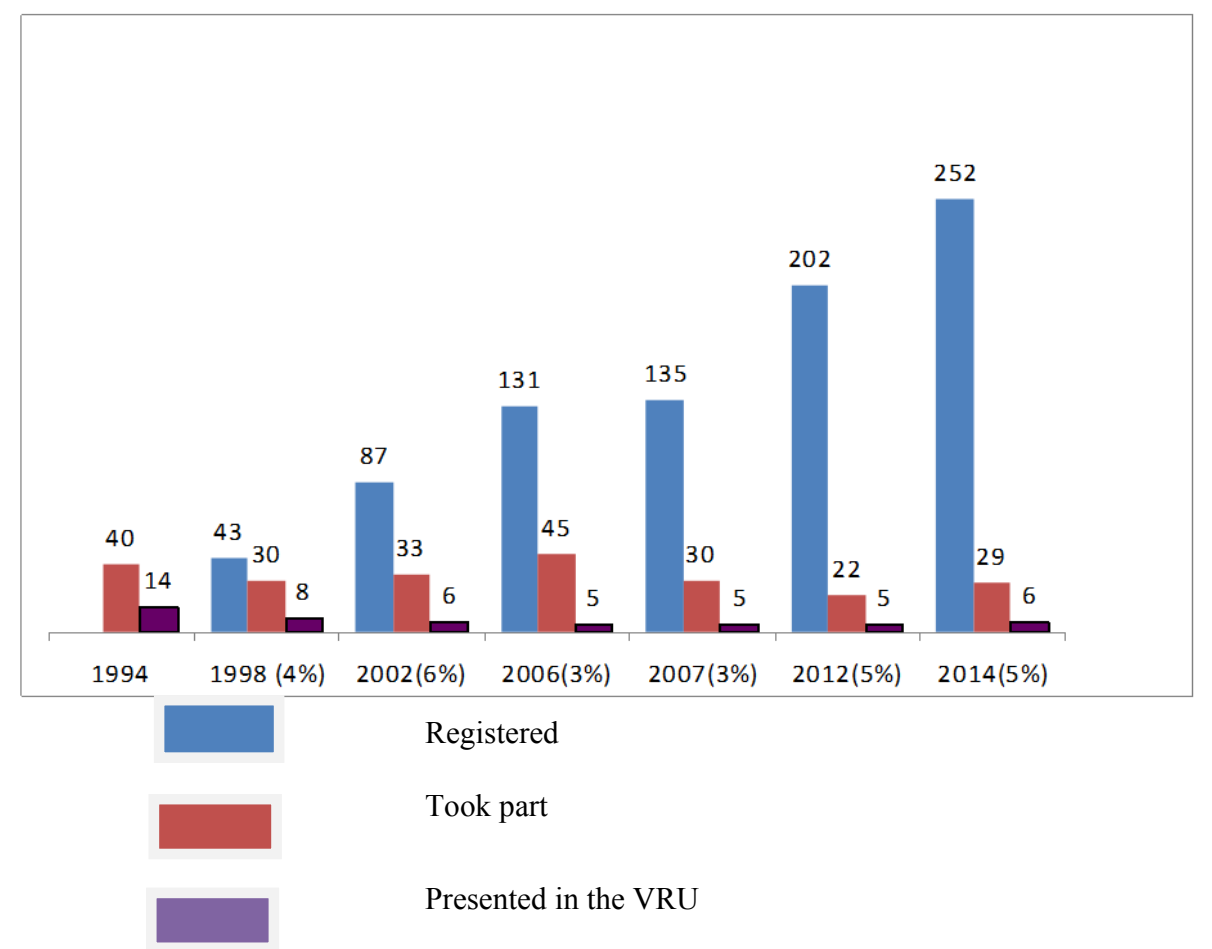

Fig. 3. Diagrams of the parliament's political structuring depending on electoral systems.

\section{Discussion}

1. The situation in Ukraine at the current stage is a consequence of the failed democratic transition, which means that the democratic transition did not lead to democracy.

A. Pshevorsky warned of this situation while characterizing the transition to democracy: "... democracy is not the only possible result of the transition process" [1]: when the end of the dictatorship comes, various strategies of development are allowed. The destruction of the autocratic regime can be turned back or lead to the dictatorship of a new model.

Degree of advancement and nature of changes in the country, which transitions to democracy can be determined by the nature of interrelated concepts of "democracy consolidation" and finished transition - democratic transition is completed if specific agreement considering the political procedures of change of government is reached and if the rise to power is the result of a free vote of the people [2].

The example of Ukraine shows that the introduction of democracy in "split" societies that have not had the experience of constitutional liberalism leads to the growth of nationalism, ethnic conflicts, and even war.

In case when democratization is carried out without liberalization (that is when elections are held, but under the conditions of guaranteed victory for the ruling party, the exclusion of certain public-political groups from participation in them, or when depriving the selected citizens of the possibility of real management) the "democradura" term is used [3]. 
As the researchers note, "the political regime in Ukraine can be viewed as a form of democracy. Such pluralization has no real influence on the political processes in Ukraine. In theory, this could be overcome by practical steps within the framework of the institutional field by creating an effective regulatory and legislative field (legality) and direct recognition by society (legitimization) [4].

2. By cultivating differences between different social groups, it complicates the processes of the consolidation of democracy, since it levels its basic principle - the search for a consensus-based on democratic principles and procedures, which should confront the practice of mutual accusations.

It is the balance that is important for the consolidation of democracy, in which the position of none of the participants is dominant. That means that the "zero-sum game", when the winner gets everything, and the player who lost, loses everything, needs to be changed to the "non-zero-sum game" for which the aggregate volume of benefits changes as a result of interaction, and the gain or loss of each is approximately equal" [5].

To assess the democratic consolidation three levels of indicators developed by L. Diamond are used, a balanced combination of which is the key to the establishment of democracy in the state [6]. The presence of any indicator has not been confirmed in Ukraine today.

The nature of democratic transit flow is also influenced by external factors, expressed in the geopolitical conditions in which the transit countries find themselves during the period of transformation. This is the so-called "binding by conditions". The term introduced by F. Schmitter means "the deliberate use of coercion by establishing special conditions for the distribution of benefits from the side of international institutions" [7].

But now we are witnessing a rather different understanding of the situation in Ukraine by international organizations, which may change due to the receipt of missing information or a new balance of forces in geopolitics and programs.

3. The specifics of the political culture of citizens and the elite and a sufficiently segmented Ukrainian society necessitate the implementation of the functions of organizing constructive dialogue on independent persons who act as arbitrators. Due to the lack of experience in democratic governance and focusing of the political elite on their interests, it was impossible to organize a productive public dialogue at the initial stage in Ukraine, neither on the elite level nor on the level of public mass organization level.

Events show that now this is impossible even with the participation of international organizations.

4. Changing the model of elections has changed the characteristics of communication between representatives of the central government and voters. Together with the abolition of the majority system of elections, the communications of the deputies with the authorities, business representatives, the public, and the public of voters were neutralized. The center for communication with voters has been moved to the offices of local organizations of parliamentary parties.

This situation further deepened the gap between the interests of the population and the activities of politicians, which became the negative side of constitutional reform. Conducted without considering democratic procedures, it became the epicenter of a new reform of the highest echelon of power and the abolition of innovations.

Thus, examples from the recent history of state reform in Ukraine prove that the choice of one or another model of government is not a guarantee of the consolidation of democracy.

The trends in the development of the Ukrainian political system showed that the legitimate change of power did not become a guarantee of the consolidation of democracy.

5. The events after the Orange Revolution have shown, and the newest ones have confirmed that in Ukraine there is a potential opportunity to stimulate the tendencies of a return to authoritarianism, and not to the consolidation of democracy. Therefore, at the 
current stage, it is extremely important to form the consensus of the elites based on formal rules of competition and procedures that will be based on public channels and mechanisms of influence and not on administrative pressure and manipulation. This will allow resolving conflict situations between key political actors only in compliance with democratic procedures established by the institutional framework.

6. At the stage of democratic transit, the demand for flexibility of power is replaced by the demand for its stability and the ability to establish mutual communication between various subjects of political life, to compromise with the opposition by involving it in the process of government decision-making, thereby depriving of the opportunity for irresponsible calls.

\section{Conclusion}

As events in Ukraine have shown, sustainable democratic governance has failed. Lack of experience of democratic traditions, low political culture, exclusion of the need to search for a compromise and coordination of positions, monopolization of power functions by one party all have an extremely negative effect on the political structure of society: democracy is limited, the people and the power are alienated from each other, the possibility of competition in political life is eliminated. The monopoly on power creates room for outrage, corrupts the holders of power and, in the end, destroys both the civil society and the state.

\section{References}

1. A. Pshevorsky, Demokratiya i rynok. Politicheskie i ekonomicheskie reformy v Vostochnoi Evrope i Latinskoi Amerike [Democracy and the market. Political and economic reforms in Eastern Europe and Latin America] (Russian Political Encyclopedia (ROSSPEN), Moscow, 1999)

2. J. Linz, Problems of Democratic Transition and Consolidation. Southern Europe, South America and Post-Communist Europe (The Johns Hopkins University Press, London, 1996)

3. F. Schmitter, Amer. Behavioral Scient. 35(4-5), 422-449 (1992). https://doi.org/10.1177/000276429203500406

4. P.M. Petrovsky, Problema institutsionalizatsiï gromadyanskogo suspilstva [The problem of institutionalization of civil society], in Proc. Sc.-Pract. Conf. Reforming the system of public administration and civil service: Theory and practice, 8 April, Lviv, Ukraine (2011)

5. D. Kovrizhenko, O. Chebanenko, V. Shramovich, Chasopis Parliament, 2, 2-26 (2008)

6. B. Makarenko, Konsolidatsiya demokratii: "detskie bolezni” postsovetskikh gosudarstv [Consolidated democracy or "Adverse beginnings" of post-Soviet states]. Accessed on: March 30, 2021. [Online]. Available: http://www.politnauka.org/library/dem/makarenko.php

7. F.K. Schmitter, Ugrozy i dilemmy demokratii [Threats and dilemmas of democracy] Accessed on: March 30, 2021. [Online]. Available: http://www.politnauka.org/library/dem/schmitter.php 